$\begin{array}{ll}\text { Italique } & \text { Italique } \\ \text { Poésie italienne de la Renaissance }\end{array}$

IV | 2001

Varia

\title{
Within and without some Collections of North Italian Court Poetry of the Fifteenth Century
}

\section{Nelia Saxby}

\section{(2) OpenEdition}

1 Journals

\section{Electronic version}

URL: http://journals.openedition.org/italique/157

DOI: 10.4000/italique. 157

ISSN: 1663-4438

\section{Publisher}

Librairie Droz

\section{Printed version}

Date of publication: 1 December 2001

Number of pages: 7-17

ISBN: 2-600-00826-1

ISSN: 1423-3983

\section{Electronic reference}

Nelia Saxby, «Within and without some Collections of North Italian Court Poetry of the Fifteenth Century », Italique [Online], IV | 2001, Online since 06 October 2009, connection on 01 May 2019. URL http://journals.openedition.org/italique/157 ; DOI : 10.4000/italique.157 


$$
\text { Nelia } \mathrm{S} \text { A X b y }
$$

\author{
W I T H I N A D W I T H O U T \\ S O M E C O L L E C T I O N S \\ OF NORTH ITALIAN COURT POETRY \\ OF THE FIFTEENTH CENTURY
}




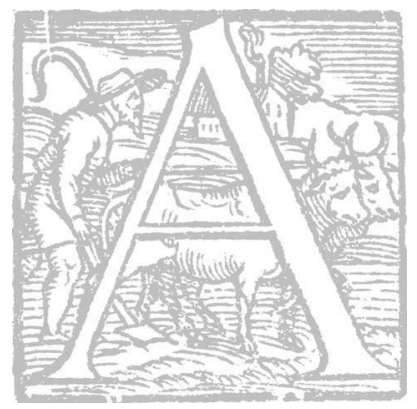

comparative survey of the coordinates of time and space in three collections of poems originating in courts of the Emilia-RomagnaMarches area is not without interest. The collections are the Versi d'amore of Giovanni de' Mantelli di Canobio, known as Tartaglia (and others):; the Rime of Francesco Palmario of Ancona, ${ }^{2}$ and those of Raniero degli Almerici of Pesaro (and others). ${ }^{3}$ The coordinate of time comprises the internal chronological arch spanned by the compositions in terms of content; the external time/times of composition, and of compilation of the collection. The coordinate of space consists of the space defined by internal references as well as the space where the book might have been presumably compiled.

I'll begin by dealing with external time and space in regard to compilation. The external features of the manuscripts are the most reliable indicators of where and when they were compiled, while the historically verifiable internal ones serve to measure the distance from the moment of original composition. Tartaglia's collection was compiled for the court of Gineura Sforza Bentivoglio. ${ }^{4}$ Among other indices of its place of compilation is the watermark, which attests to its Bolognese origin.' It was finalized certainly between I49I and I506, year in which the Bentivoglio were obliged to flee Bologna. ${ }^{6}$ Thus it may be said to be coeval with the closing years of Bentivoglio rule and magnificence in Bologna.7 Historians have generally indicated that the fall from power of the Bentivoglio family was accelerated by the extermination, in May I50I, of the Marescotti family and have attributed responsibility for this mainly to Ginevra. Her action earned her the hostility and the antagonism of the Bolognesi, already not well-disposed towards her. ${ }^{8}$

Palmario's collection was compiled for Sigismondo Malatesta. This is made clear by the opening two poems. The handwriting would seem to date the manuscript, a finalized copy, to the final decades of the fifteenth century.9 Its original compilation would seem to have taken place in the I460s when Sigismondo Malatesta's state and court were in the process of being destroyed by the implacable hatred of Pius II. ${ }^{10}$ The space of its compilation is less easy to define. There is documentary proof that by 1460 Palmario had returned to his native Ancona and in the service of his city. In that year he acted as the city's emissary to Sigismondo to request his aid for one of Ancona's skirmishes with a neighbouring town. ${ }^{\text {II }}$ Unlike Tartaglia's collection, neither watermarks nor coats of arms aid in establishing place of compilation, so on purely bypothetical grounds, it is likely that it was in Ancona that Palmario (or his heirs) ordered the transcription of the final copy of his verses. The space left at the 
top of the title page for an incipit, the lack of illuminated capitals, would seem to indicate that the project of presenting the book to the Malatesta had fallen through. This in turn, confirms the later dating of the collection. Almerici's collection of verse ends abruptly with a lament on the death of Costanzo Sforza: bence, with the year $1483 .{ }^{12}$ The division in folios bound in quarto, except for the final page which is the first of an incomplete folio, would lead to the deduction that the book in its present form is incomplete. This would also be borne out by the corrections, variants and deletions in the text itself which would validate it as an autograph copy. ${ }^{13}$ Transcription and compilation were certainly completed by I499, year in which final mention is made of Almerici in civic records of Pesaro. ${ }^{\text {I4 }}$ The signs of incompletion in the book would seem to indicate also that Almerici abandoned any notion whatsoever of presenting it to Costanzo's successor, Giovanni. Instead, it is likely that he continued to revise his verse during the last years of bis life.

Almerici's collection diverges from the first two not only because it is an autograph but also because of the number of rubrics which indicate the occasions for which some of the poems were composed and by whom (or by whose commission). ${ }^{15}$ To the rubrics might well be assigned a mnemonic function for both writer and reader. One of their subsidiary functions is to contextualise the poems in the reality of time and space.

All three collections, ironically, belong to the end of an era of the court for which they were intended. They are retrospective in character and present a public and private universe that is no longer extant in reality. In terms of literary history they may be said to be the last products of what Santagata has defined as early court poetry. ${ }^{16}$

I come now, to internal time, the chronological arch spanned by the internal, verifiable references to events and characters and as a consequence, to internal space, defined by events and place-names.

Since from both aspects the most complex collection is Tartaglia's, it would be appropriate to handle it first. It differs from the other two in that it contains, as the manuscript tradition has confirmed, at least five poems which are certainly not his and whose known period of composition forms an arch that begins with the final decade of the fourteenth century and ends with that of the fifteenth century. ${ }^{17}$ The internal historical references which can be dated with certainity span the period I435-36 to I462. Central to these is the allusion to the Peace of Lodi of I454, in the ternario LXXXviII in praise of Francesco Sforza's military career.

Internal space is as vast as internal time. The place-names, both explicit and implicit, span the area of Emilia, Romagna and the Marches: Bologna, Forli, Faenza, Fano, and, in prevalence, Pesaro. If to these are added the probable places of origin of four of the five poems whose manuscript tradition 
confirms that they cannot be by Tartaglia, the area broadens to include Lombardy and Florence. The spaces indicated by the place-names have in common that they were all, without exception, under the rule of families which were either Bentivoglio-friendly or Sforza-friendly or both.

Singularly absent from the collection (with the exception of the ternario to Francesco Sforza), is any reference to historical events of national and even of municipal importance. The court as a space is also absent. Its inhabitants, if the personages are to be indentifed in the Bentivoglio context, are merely alluded to by proper names and not individuated in a bistorically verifiable way. The reference to Ginevra herself is through the senhal of unn bel ginepros in the penultimate poem.

The striking feature of the collection is that it represents over a century of poetry of different styles and modes. It may be defined as the municipal equivalent of the Raccolta Aragonese and reflects the readership tastes of a small and exclusive audience, the intellectual space, then, of a court as interpreted by one of its dependents, rather than the court itself.

Less dispersive are the coordinates of space/time in Palmario's collection. Internal space spans the period I445-60, with greater weight given to the decade of the Fifties when archival sources record Palmario as a dependent of the Malatesta for the period I454-56. The space coordinate conforms with time in the division Ancona-Rimini. In the decade of the Forties Palmario was on the bunt for a patron, bence the compositions addressed to ecclesiastical dignitaries who were in a position to exert influence on Ancona's political situation and the only canzone in praise of Sigismondo as a military leader for the period $1445-48 .{ }^{18}$

There is no similar composition addressed to Francesco Sforza who, in the early Forties was one of the most powerful military figures to control affairs in the Marches. ${ }^{19}$ To Sforza Palmario had instead addressed in 1445 the coniugalis sermo. ${ }^{20}$ Subsequent poems in Palmario's collection reflect the cultural propaganda of the court that required that the myth of the love-affair between Sigismondo and Isotta degli Atti be immortalized in art as well as in literature. ${ }^{21}$ In no other collection does the court as the space for cultural achievements appear as explicitly as in Palmario's. He pays homage to the poets of the court, Giusto dei Conti, Leon Battista Alberti (via reminiscences of Alberti's own poems, mainly in the polimetro XxxvII), to the author(s) of the Liber Isotteus (LXXIV). Art as well as literature are commemorated: the Tempio Malatestiano itself is recalled by allusions to the bronze plaque and epigraph on Isotta's sarcophagus (Lxxxvin, Cv). So is Matteo de' Pasti, whose medals, bearing the portrait of Isotta on the one side and the script, Elegia, on the other, were coined on commission between I456 and I460 (LXXXIV). 
Literature is also represented by the figure of Sigismondo as lover and poet. As a man of war, he is, after the first canzone, absent. It is as though Palmario had prudently and deliberately decided to overlook Sigismondo's campaigns leading up to his downfall and to the loss of his State. Alongside the Malatesta, there is Palmario himself, in the role of lover, love poet but also poet of political verse.

The internal time in Almerici's collection spans a period of twenty-one years, from 1462 to 1483 . The earliest historically verifiable allusion that it contains is to Alessandro Sforza's victory over Iacomo Piccinino. ${ }^{22}$ The collection begins, therefore, seventeen years after Alessandro had bought Pesaro from Galeazzo Malatesta. ${ }^{23}$ It concludes with the death of his heir, Costanzo. At its mid point, or near enough, it commemorates the death of the greatest of the Sforzas, Francesco (I466). ${ }^{24}$ The space coordinate includes, besides Pesaro and the nearby town of Talachio, Milan, the Abruzzo and its administrative capital Teramo, Monte San Severino and the baths of Petriolo (Siena).

Without exception these places have some connection with Sforza enterprises. Milan, as the seat of senior Sforza administration, the Abruzzo, as the scene in which Alessandro Sforza obtained both glory and titles, Petriolo and Monte San Severino, areas in which Costanzo, together with Almerici, saw action during the Florentine war of $1478-79 .^{25}$

In relation to the previous two collections, Almerici's is exceptional on a number of points. Firstly, it records le donne e gli amor, gli agi e gli ozii of court life. ${ }^{26}$ It is understandable, therefore, that the personages mentioned are closely linked to the court. ${ }^{27}$ It is the place to which Almerici bimself belongs, by right of descent, wealth, position and profession, miles, conte e cavaliere as he is referred to by archival records. ${ }^{28}$ Of the three collections, it is the only one composed and compiled by an "insider" who feels it legitimate to record his personal details with those of his characters. The collection thus acquires the character of a diary or of a memorandum of family and family-related events.

As Olivieri puts it in his biographical note, Almerici was the confidante of Alessandro's and Costanzo's love-affairs. He was also the recorder of these and, in the case of Alessandro, of his religious "conversion" as well. From Alessandro's turbulent sentimental life, Almerici chooses to mention only Pacifica Samperoli, ${ }^{29}$ whose right to exist in literature had been consecrated in the exchange of sonnets between Alessandro and Angelo Galli. ${ }^{3 \circ}$

His view of court love-affairs is selective, in conformity with the petrarchan ideal, but possibly for reasons of court and family diplomacy as well. For the Almericis, seeing which way the wind was blowing, had succeeded in establishing strong family bonds with the Samperolis through brilliant marriages. ${ }^{3}$ By placing Pacifica in a position of prominence through exclusivity, 
Almerici ensures that she retain in history her role as Alessandro's donna.

Although there is mention of love-affairs in Costanzo's life, with care taken not to reveal the identity of the lady in question, the focus is on the figure of his wife. Camilla Marzana appears in the conventional role of the irreproachable consort of the lord as well as in the unconventional, domestic one of a friend of the Almericis. The somewhat banal episode of her gift of a kilt to Almerici's youngest child, Africano, becomes the pre-text for a sonnet in which Almerici takes the opportunity of stating his kinship with the Sforzas and the loyalty of his family to them. ${ }^{32}$ Thus, the public figure is brought into the context of the private life of the author. Almerici bimself presents his private and domestic image rather than his public one. He is the woebegone widower lamenting the death of his first wife, Lucrezia. ${ }^{33}$ Later, he is the happy fiancé of Ginevra, whose name be commemorates with an acrostic sonnet, composed for their betrothal. ${ }^{34}$

It is the banal and the facetious that predominate in this collection of poems. The pomp of public ceremonies such as Costanzo's wedding feast are aspects which are not illustrated. ${ }^{35}$ Instead, the death of the bunting dog, Leone, during a boar-bunt organized by Pacifica's brother, Francesco, and attended by Costanzo, becomes matter for poetry. ${ }^{36}$

The role assumed by Almerici in his collection is that of court poet who composes on request and engages in poetic correspondence on mainly amatory topics. Death, as the second great theme of the lyric tradition is also present. Not, however, in the form of the lover's lament, but of the father's. For Ser Matteo dei Collenucci di Sassoferrato, father of the bumanist, Pandolfo, and related to the Almericis by marriage, ${ }^{37}$ there is the cycle of poems lamenting the death of his daughter, Camilla (possibly I463-65). ${ }^{38}$ Thus, even the great theme of the "tragic" register is brought down to the level of the domestic.

The reality of life outside the court is evoked only once, in the great final canzone. It is a lament for the sudden death of Costanzo, as both worthy condottiere and lord of Pesaro. In this composition the city-state of Pesaro appears with its fortress, walls, butresses and towers as a city created for the security of its subjects by Costanzo bimself.

In Almerici's collection the court and its inbabitants are seen from the perspective of an insider who bimself has titles, money and position. The quotidian and the occasional, the private and even the banal of court life can be legitimately included because of the intricate web of family connections which bind the characters belonging to it. The court begins to acquire the character of an extended family home which excludes the notion of a socialbierarchy.

In these three coeval books of verse, originating from within the same topographical boundaries, court space and space of the court both in real terms and 
temporal ones diverge markedly from each other. The court as an intellectual space, whose cultural boundaries are formed by political and diplomatic motivations is represented in Tartaglia's collection, the court as the place of cultural achievement is illustrated in Palmario's, and finally, in Almerici's there is the private and domestic aspect of court society. External reality is minimized. Where it is allowed to intrude on the ideal world represented by the poems, it does so, as in the case of Palmario, for specific professional motives.

Nelia Saxby 


\section{Collections of North Italian Court Poetry}

i. Giovanni de' Mantelli di Canobio, detto Tartaglia (ed altri), Versi d'amore, a cura di N. Saxby, Bologna, Commissione dei Testi di Lingua, 1985. For the full bibliography, pp. XI-XLVI of the Introdurione to the edition and The Book of Poetry at the End of the Fifteenth Century. The "Case" of the «Amatori Versus», in press in «Letteratura Italiana Antica».

2. Francesco Palmario, Rime, a cura di N. Cacace Saxby, Bologna, Commissione dei Testi di Lingua, I997. For the background and full bibliography of what is to follow, pp. IX-LV of the Introduzione.

3. Biblioteca di Classe, Ravenna, Cod. 240. The ms. was summarily described by S. Bernicoli in G. Mazzatinti, Inventari dei manoscritti delle biblioteche d'Italia. Ravenna, Forlì, Bordandini, I 894-95, vol. IV, p. I 99. There is a more complete description and transcription of some poems by: P. Lorenzetti, Rainero degli Almerici, rimatore pesarese della seconda metà del Quattrocento, «La Romagna», X (1913), pp. 437-5 5.

4. B. Bentivogli, rec. a Giovanni de' Mantelli di Canobio, detto Tartaglia (ed altri), Versi d'amore cit., «Studi e problemi di critica testuale», XXXII (1986), pp. I 88-96. In his essay: La poesia in volgare. Appunti sulla tradizione manoscritta, in Bentivolorum magnificentia. Principe e cultura a Bologna nel Rinascimento, a cura di B. Basile, Roma, Bulzoni, I984, pp. 177-222, B. Bentivogli observed that the question of whether in Bologna there was in fact a form of «court literature» still remains to be clarified (p. 179 note 3).

5. C. M. Briquet, Les Filigranes. Dictionnaire bistorique des Marques du Papier dès leur Apparition vers I282 jusqu'en 1600, Leipzig, Verlag von Karl W. Hiersmann, I923, vol. III, nos. I 17 I I- I 5 , p. 588.

6. The penultimate poem in Tartaglia's collection, cxLII bears the rubric: Giorno felice di Tartaglia nelli Campi Elisii. Bentivogli pointed out its presence, in an incunabulum entitled Silvano, which contains the collected poems of «misser Thomaso Sclaricino Gammaro, doctore in leze de Bologna», printed «a comune spesa de Benedetto de Hector libraro e de Plato di Benedetti stampatore, Regnante lo Illustre S. Signor Zohanne di Bentivogli nel MCCCLXXXXI a dì XI, Luglio». The date of I49I is based on the existence of the poem in Gambaro's collection. Bentivogli attributes it to Gambaro himself. There are four extant copies of the incunabulum. One is held by the Biblioteca dell'Archiginnasio of Bologna, a second copy by Biblioteca Nazionale di Firenze, shelf-mark E., 6, 3, 49 (IGI 4I67 GW I0538). For Gammaro: M. E. Cosenza, Biographical and Biliographical Dictionary of the Italian Humanists and of the World of Classical Scholarship in Italy, I300-I800, Boston, Massachusetts, G.K. Hall and Co., 1962, vol. 2, col. 2; Giovanni Fantauzzi, Notizie degli scrittori bolognesi, Bologna, San Tommaso d'Aquino, 1784-94, vol. 4, pp. 50-54, s.v. Gambaro.

7. The events of the final years of Bentivoglio rule are recorded by: Cherubino GhirarDACCI, Della Historia di Bologna, a cura di A. Sorbelli, Città di Castello, Lapi, I 9 I 2-32, vol. III, pp. 346-75.

8. C. Albicini, Di Galeazzo Marescotti de' Calvi da Bologna e della sua cronaca, «Archivio storico italiano», XVI, XXI, XXII (I 873-1875), pp. 30-54, pp. 397-430, pp. 37-49.

9. I am indebted to Teresa De Robertis for the dating.

I o. G. Soranzo, Un'invettiva della Curia romana contro Sigismondo Malatesta, «La Romagna», VIII (1910), pp. 462-89, (191 I), pp. I 50-75; Id., La tragica sorte dello stato di Sigismondo Pandolfo Malatesta, «Studi Romagnoli», II (I95 I), pp. I97-2 I 2.

ir. Lazzaro Bernabei, Croniche anconitane, a cura di C. Ciavarini, Bologna, Forni, i976 (reprint), vol. I, p. I 82. 


\section{Nelia Saxby}

I 2. Se Italia piangi saffligi e tormenta foll. $7 \mathrm{IV}-73 \mathrm{v}$. For the Sforzas of Pesaro, a brief biographical summary in Pompeo Litta, Famiglie celebri d'Italia, Milano, Giusti, vol. I, i 8 I 9, tav. I4. Of general interest is C. Santoro, Gli Sforza, Varese, Dall'Oglio, I968.

I 3. Almerici also transcribed a copy of Giusto dei Conti's Canzoniere, now held by the Biblioteca Oliveriana of Pesaro as Cod. 55. There is a note to that effect in the ms., reported by M. Santagata, Fra Rimini e Urbino: i prodromi del petrarchismo cortigiano, in M. Santagata - S. Carrai, La lirica di corte nell'Italia del Quattrocento, Milano, Franco Angeli, I 993 , pp. 43-95, p. 59 note 56 . A comparison of the hands confirms that Cod. 240 of the Classense is autograph.

I4. The Ravenna ms. of the Rime includes the nota biografica on Almerici by Annibale Olivieri. It is a compilation of information which he found in the records still held at the Biblioteca Oliveriana of Pesaro.

I 5 . A further proof that the ms. is an autograph is the cypher «RA» which concludes most of the rubrics.

\section{I6. M. Santagata, La forma «Canzoniere», in La lirica di corte cit., pp. 31-39.}

17. In the order in which they appear in the edition these are: xxxvI, the Reprensione contra Manganello by Antonio Cornazzano; LVII, attributed to Astorre Manfredi by the manuscript tradition but in fact by Malatesta Malatesti; cxiv dated to the final decade of the Trecento; CXXI attributed to Gianotto Calogrosso; cxxxiv of the mid-fifteenth century; CXLII attributed to Tommaso Gambaro.

I8. Cronaca malatestiana di ser BALDO BRANCHI, in Cronache malatestiane dei secoli XIV e XV, a cura di A. F. Massera, in Raccolta degli storici italiani dal 500 al I500, Bologna, Zanichelli, I922, vol. XV, part 2, pp. I $25-27$.

19. G. Bennaduci, Della signoria di Francesco Sforza nella Marca e particolarmente in Tolentino: dicembre I433-agosto I447, Bologna, Forni, I980 (reprint), pp. 325-28.

20. P. O. Kristeller, Iter Italicum, vol. III, London, Warburg, I983, \$564b.

21. On the phenomenon of "Isottismo", together with a full bibliography on what is dealt with in the text, A. Campana, s. v. Atti, Isotta degli, in Dizionario biografico degli Italiani, Roma, Treccani, vol. IV, I962, pp. 547-56; and s. v. Basinio, Ibid., vol. VII, I965, pp. 89-98.

22. Folio $3 \mathrm{v}$. The sonnet bears the rubric: Nel tornar che fe lo Ill. S. nosto a Pesaro poichebbe rotto il conte Iachomo Piccinino. Lorenzetti dates it to $\mathrm{I} 46 \mathrm{O}$.

23. On Alessandro Sforza, the most complete source of information is Annibale Olivieri Degli Abbati, Memorie di Alessandro Sforza, signore di Pesaro, Pesaro, Gavelli, 1785.

24. Published by P. Lorenzetti, Rainero cit., p. 449 No. I.

25. On Costanzo Sforza's military career, G. Canestrini, Documenti per servire alla storia della milizia italiana, «Archivio storico italiano», XV (1 85 I), pp. LXXXIV-V, pp. $190-225$ (for the Documenti). On the Florentine campaign in particular: F. Ambrogiani, Immagini di Costanzo Sforza e Federico da Montefeltro alla guerra di Toscana del 1478 -9, «Pesaro città e contà», 2 (1992), pp. 87-92; and Id., La partecipazione di Costanzo Sforza alla guerra di Toscana del I478-9, «Pesaro città e contà», 7 (1996), pp. I I-30. 


\section{Collections of North Italian Court Poetry}

26. On this aspect of court life, P. Parroni, La cultura letteraria a Pesaro sotto i Malatesta e gli Sforza in Pesaro tra Medioevo e Rinascimento a cura di M. R. Valazzi, Venezia, Marsilio, I989, pp. 203-22.

27. The internal administration of court life is explained by S. Eiche, Towards a Study of the "Famiglia" of the Sforza Court of Pesaro, «Renaissance and Reformation», IX (I985), pp. 79-I I I.

28. The most informative is the "scheda" s. v. Raniero Almerici. Biblioteca Oliveriana, Cod. 458 , Schede di illustri pesaresi, vol. I, VII.

29. There exists no biography of Pacifica. Her relationship with Alessandro, her "conversion" and marriage are dealt with by Olivieri, Memorie di Alessandro Sforza, pp. 80-84, pp. 90-97; B. Feliciangeli, Sulla monacazione di Sveva-Montefeltro signora di Pesaro. Ricerche, Pistoia, Flori, I903, pp. 38-43. A rich source of information on the Samperoli family can be found in the "schede" s. v. Samperoli of Cod. Oliv. 458, vol. V.

30. Angelo Galli, Canzoniere, a cura di G. Nonni, Urbino, Accademia Raffaello, I987, no. 348 .

3 I. A. Saviotti, Una sorella del Collenuccio, «Le Marche illustrate nella storia, nelle lettere, nelle arti», IV (I 904), pp. 306-I6, p. 308; also, Cod. Oliv. 458, vol. I, s. v. Almerico Almerici III.

32. For Camilla are the sonnets: Credo che Gioue nel suo magistero, (fol. 7or); Non come a tal madonna se conuiene (fol. $7 \mathrm{Ir}$ ).

33. There are six poems in all, on foll. $49^{\mathrm{r}-52 \mathrm{v}}$. P. Lorenzetti, Rainero cit., published the sestina, pp. 450-5 I.

34. Giamai dal cor lamor da dio concesso (fol. 7or).

35. Costanzo's marriage feast is described in detail in the Descrizione del convito e delle feste fatte in Pesaro per le nozze di Costanzo Sforza e di Camilla d'A ragona nel maggio, I475; ed. M. Tabarrini, Firenze, Barbera, I 870 . More recently, on the topic, G. Arbizzoni, Note sull" Ordine delle noze» di Costanz̧o Sforza e Camilla d'Aragona, «Studi piceni», XV (I995), pp. 9-17.

36. It is the sonnet beginning: Patron gentil tu uedi chora alfine (fol. $32 \mathrm{r}-\mathrm{v}$ ); P. Lorenzetti, Rainero cit., p. 449 .

37. A. Saviotti, Una sorella cit., p. 309 note 3.

38. The four poems on foll. $32 \mathrm{v}-34 \mathrm{v}$ have been published by A. Saviotti, Una sorella cit., PP. 3 IO-I3. 